\title{
Evaluation of the in vitro efficacy of non-beta-lactam antibiotics in extended-spectrum beta-lactamase-producing and non-producing Klebsiella spp. and Escherichia coli strains
}

\section{Genişlemiş spektrumlu beta-laktamaz üreten ve üretmeyen Klebsiella spp. ve Escherichia coli suşlarında beta-laktam dışı antibiyotiklerin in vitro etkinliğinin değerlendirilmesi}

\author{
(DGöknur Yapar Toros ${ }^{1}$, @Funda Timurkaynak ${ }^{2}$ \\ ${ }^{1}$ University of Health Sciences Dr. Abdurrahman Yurtaslan Ankara Onkoloji Training and Research Hospital, Department of \\ Infectious Diseases and Clinical Microbiology, Ankara, Turkey \\ ${ }^{2}$ Cenevre University Hospital, Infectious Control and Prevention Department, Geneva, Switzerland
}

Cite this article as / Bu makaleye atıf için: Yapar Toros G, Timurkaynak F. Evaluation of the in vitro efficacy of non-beta-lactam antibiotics in extended-spectrum beta-lactamase-producing and non-producing Klebsiella spp. and Escherichia coli strains. J Med Palliat Care 2021; 2(2): 47-53.

\begin{abstract}
Objective: Bacteria develop resistance to many antibiotics by using different mechanisms. The resistance of bacteria secreting extendedspectrum beta-lactamases to many antibiotics limits our treatment options. In this study, we investigated the in vitro efficacies of non-betalactam antibiotics in Escherichia coli (E. coli) and Klebsiella spp. strains.

Material and Method: In our study, we investigated the presence of ESBL in 97 ESBL-negative (61 E. coli, 36 Klebsiella spp.) and 54 ESBLpositive (33 E. coli, 21 Klebsiella spp.) strains of nosocomial origin isolated from blood culture through a phenotypic confirmation test. We determined in vitro efficacies of aminoglycoside and quinolone group antibiotics by the agar dilution method.

Results: The susceptibility rates of ESBL- non-producing and producing strains were $81.4 \%-48.1 \%$ to ciprofloxacin, $85.5 \%-50 \%$ to levofloxacin, $81.4 \%-46.3 \%$ to ofloxacin and moxifloxacin, $99 \%-37 \%$ to gentamicin, $97.9 \%-57.4 \%$ to netilmicin, and $99 \%-96.2 \%$ to amikacin, respectively.

Conclusion: In our study, we found that all aminoglycoside and quinolone group antibiotics showed low efficacies. Amikacin had the highest in vitro activity in E. coli and Klebsiella spp. strains.

Keywords: Extended-spectrum beta-lactamase, aminoglycoside, quinolone, minimal inhibitory concentration
\end{abstract}

\section{ÖZ}

Amaç: Bakteriler bir çok antibiyotiklere farklı mekanizmaları kullanarak direnç geliştirmektedir. Genişlemiş spektrumlu beta-laktamaz (GSBL)-üreten bakterilerin pek çok antibiyotiğe karşı dirençli olmaları tedavi seçeneklerimizi kısıtlamaktadır. Bu çalışmada in vitro olarak Escherichia coli (E. coli) ve Klebsiella spp. suşlarında beta-laktam dışı antibiyotiklerin etkinliğini araştırdık.

Gereç ve Yöntem: Çalışmamızda kan kültüründen izole edilen nozokomiyal kökenli 97 GSBL-negatif (61 E. coli, 36 Klebsiella spp.) ve 54 GSBL-pozitif (33 E. coli, 21 Klebsiella spp.) suşunda GSBL varlığı fenotipik doğrulama testi ile araştırıldı. Aminoglikozid ve kinolon grubu antibiyotiklerin in vitro etkinlikleri agar dilüsyon yöntemi ile belirlendi.

Bulgular: GSBL-üreten ve üretmeyen suşların duyarlılık oranları sırasıly siprofloksasin için \%81,4-48,1; levofloksasin için \%85,5-50; ofloksasin ve moksifloksasin için \%81,4-46,3; gentamisin için \%99-37; netilmisin için \%97,9-57,4 ve amikasin için de \%99-96,2 olarak bulundu.

Sonuç: Çalışılmamızda E. coli ve Klebsiella spp. suşlarında tüm aminoglikozid ve kinolon grubu antibiyotiklerin etkinliğinin düşük olduğu; amikasinin en yüksek in vitro etkinliğe sahip olduğu görüldü.

Anahtar Kelimeler: Genişlemiş spektrumlu beta-laktamaz, aminoglikozid, kinolon, minimum inhibitor konsantrasyon 


\section{INTRODUCTION}

The extended-spectrum $\beta$-lactamase (ESBL), which is widely detected all over the world, was first defined in 1983 (1). Regardless of the susceptibility results of ESBL-producing bacteria, infections with these bacteria are of clinical significance because they are considered resistant to all penicillins, cephalosporins (except for cefamicins (cefoxitin, cefotetan, cefmethazol, and moxalactam)), and aztreonam. Although these bacteria are susceptible to beta-lactam/beta-lactamase inhibitor combinations, recent surveillance data show that the number of strains that cannot be treated with these antibiotic combinations is also increasing (2). ESBL enzymes have recently been demonstrated with increasing frequency in Gram-negative bacteria, especially in Escherichia coli (E. coli) and Klebsiella spp. strains. It is worrisome that an international multicenter study determined that our country had the incidence of Klebsiella spp. strain producing the highest ESBL (3). There are many clinical studies showing that carbapenems are active in ESBL-producing bacterial infections, but the drawbacks of widespread use of carbapenems should not be ignored (4).There are limited studies in the literature on the susceptibility rates of ESBL-producing E. coli and Klebsiella spp. strains to different antibiotic classes, such as quinolone and aminoglycoside (5).

Overall, this study aimed to determine the susceptibility of ESBL-producing and non-producing E. coli and Klebsiella spp. strains to aminoglycoside and quinolone group antibiotics and to uncover the role of these antibiotics in the treatment of infections due to ESBLproducing bacteria.

\section{MATERIALS AND METHOD}

\section{Ethical Approval}

We obtained the relevant approval for our study from Başkent University, Non-Invasive Health Research Ethics Committee (Date: 11.05.2005, Decision No: 2004/AP577). We strictly ensured that all procedures were carried out in accordance with the 1964 Helsinki Declaration and the ethical standards of national/institutional scientific research committees.

\section{Data Collection}

We examined E. coli and Klebsiella spp. strains isolated from non-urine samples of the patients hospitalized in Başkent University Hospital between 2003-2004 by ESBL secretion. As a result, 54 ESBL-producing and 97 non-ESBL-producing strains were included in the study.

\section{Identification of Enteric Bacteria}

We used Bactec-9050 (Becton Dickinson, Maryland, USA) automated blood culture system for blood cultures. Samples giving positive growth signals in the culture system were passaged into eosin methylene blue (EMB) and blood agar. We studied the bacteria grown on EMB agar and determined to be E. coli and Klebsiella spp. by their growth characteristics in indole production test, methyl red and citrate tests, urea hydrolysis test, and three sugar iron agar (TSI). Bacteria included in the study were stored at $-20^{\circ} \mathrm{C}$ until the study day.

\section{ESBL Test}

We used ceftazidime/ceftazidime-clavulanic acid phenotypic confirmation test to detect ESBL-bearing strains. (6). Accordingly, we placed discs containing ceftazidime $(30 \mu \mathrm{g}) / \mathrm{ceftazidime}$-clavulanic acid $(10 \mu \mathrm{g})$ on MHA (Oxoid, Hampshire, England) plates where bacterial suspensions with McFarland 0.5 density were spread and incubated at $35^{\circ} \mathrm{C}$ for 18 hours. After incubation, we measured and compared inhibition zones around discs with and without clavulanic acid. Bacteria were considered positive for ESBL production when the zone diameter around the combination discs was $5 \mathrm{~mm}$. or larger than the zone diameter around the disc without clavulanic acid.

\section{Antibiotic Susceptibility Tests of Isolated Strains}

We determined the minimum inhibitory concentration (MIC) values of the strains included in the study by the agar dilution method (49). Antibiotic potent powders (Sigma, St Louis, USA) were used in the susceptibility test. Also, we utilized E. coli (ATCC, 25922) and Pseudomonas aeruginosa ( $P$. aeruginosa) (ATCC, 27853) standard strains as control strains in the study. We evaluated the MIC values of the bacteria included in the study (Table 1) in line with the recommendations of the Clinical Laboratory Standards Institute (CLSI) (6).

\begin{tabular}{|c|c|c|c|c|c|}
\hline Antibiotic & Susceptible & Intermediate & Resistant & E. coli & $\begin{array}{c}P . \\
\text { aeruginosa }\end{array}$ \\
\hline Ciprofloxacin & 1 & 2 & 4 & $0.004-0.015$ & $0.25-1$ \\
\hline Levofloxacin & $\leq 2$ & 4 & $\geq 8$ & $0.008-0.06$ & $0.5-4$ \\
\hline Ofloxacin & $\leq 2$ & 4 & $\geq 8$ & $0.015-0.12$ & $1-8$ \\
\hline Moxifloxacin & $\leq 0.5$ & 1 & $\geq 2$ & $0.008-0.06$ & $1-8$ \\
\hline Gentamicin & 4 & 8 & 16 & $0.25-1$ & $0.5-2$ \\
\hline Amikacin & 16 & 32 & 64 & $0.5-4$ & $1-4$ \\
\hline Netilmicin & 8 & 16 & 32 & $0.5-1$ & $0.5-8$ \\
\hline
\end{tabular}

We calculated the amount of antibiotic required for MIC determination by the agar dilution method using the following formula:

Antibiotic powder weight (amount to be weighed $)=$ Volume $(\mathrm{ml}) \times$ desired concentration $(\mu \mathrm{g} /$ $\mathrm{ml}$ )/Antibiotic activity ( $\mu \mathrm{g} / \mathrm{mg})$. 
We prepared stock solutions for each antibiotic. Table 2 presents stock, solvent, and diluent liquids used in preparing solutions for the antibiotics studied.

\begin{tabular}{|c|c|c|}
\hline Antibiotics & Solvents & Diluents \\
\hline Amikacin & Water & - \\
\hline Netilmicin & Water & - \\
\hline Gentamicin & Water & - \\
\hline Ciprofloxacin & Water & - \\
\hline Ofloxacin & $\begin{array}{l}1 / 2 \text { volume of water, then } 0.1 \mathrm{~mol} / \mathrm{L} \\
\mathrm{NaOH} \text { is dripped until dissolved }\end{array}$ & - \\
\hline Levofloxacin & $\begin{array}{l}1 / 2 \text { volume of water, then } 0.1 \mathrm{~mol} / \mathrm{L} \\
\mathrm{NaOH} \text { is dripped until dissolved }\end{array}$ & Water \\
\hline Moxifloxacin & Water & - \\
\hline
\end{tabular}

We prepared serial dilutions in two-fold such that the MIC range was $0.5-128 \mu \mathrm{g} / \mathrm{ml}$ for the quinolone group antibiotics and $0.0625-32 \mu \mathrm{g} / \mathrm{ml}$ for the aminoglycoside antibiotics. We utilized daily prepared Mueller-Hinton agar (MHA) as the medium. Before the study, we prepared bacterial suspension at $0.5 \mathrm{McF}$ arland density $(108 \mathrm{cfu} / \mathrm{ml})$ by passaging the bacteria. $10 \mu \mathrm{l}$ of antibiotic dilutions from this suspension were spread on MHA plates, and plates were incubated at $35^{\circ} \mathrm{C}$ for $18-24$ hours. We determined the lowest concentration without growth as the MIC value. When calculating the susceptibility rates, strains with intermediate sensitivity were included in the susceptible category. For the quality control of the study, we observed that there was no growth in the sterility control plate, all bacteria were grown in the growth control plate, and the MIC values of the control strains were within the CLSI-recommended MIC range.

\section{Statistical Analyses}

We used percentage and mean values while presenting the data. We run the Chi-square test and Fisher's exact test for the statistical analyses of the data. Those with a p-value of $<0.05$ were considered significant. We used SPSS 22.0 (IBM Institute, North Castle, USA) program for all statistical analyses.

\section{RESULTS}

\section{Features of Strains}

We determined that 195 (48.6\%) of 401 E. coli strains and 98 (35.5\%) of 276 Klebsiella spp. strains were ESBLpositive. We kept conducting the study on a total of 151 strains composed of 97 ESBL-negative (61 E. coli; 36 Klebsiella spp.) and 54 ESBL-positive (33 E. coli; 21 Klebsiella spp.), which were bacteremia agents among the samples.

\section{Antibiotic Susceptibility Results}

Of the ESBL-negative (E. coli+Klebsiella spp.) strains included in the study, $99 \%$ were susceptible to amikacin, $99 \%$ to gentamicin, and $97.9 \%$ to netilmicin. When quinolone group antibiotics were considered, susceptibility rates were $81.4 \%$ to ciprofloxacin, $85.5 \%$ to levofloxacin, $81.4 \%$ to ofloxacin, and $81.4 \%$ to moxifloxacin. We found those rates of GSBL-positive strains were $96.2 \%$ to amikacin, $37 \%$ to gentamicin, and $57.3 \%$ to netilmicin, $48.1 \%$ to ciprofloxacin, $50 \%$ to levofloxacin, and $46.2 \%$ to ofloxacin and moxifloxacin.

When the susceptibility rates of all ESBL-positive and negative strains were evaluated statistically, we discovered that those rates to all antibiotics, except amikacin, were significantly decreased in ESBLpositive strains $(p<0.0001)$. The susceptibility rates of 151 strains to the mentioned antibiotics are given in Table 3.

\begin{tabular}{|lccc|}
\hline \multicolumn{4}{|c|}{$\begin{array}{c}\text { Table 3. Susceptibility rates of ESBL-positive and negative E. coli } \\
\text { and Klebsiella spp. strains to the antibiotics studied }\end{array}$} \\
\hline $\begin{array}{c}\text { Susceptibility } \\
\text { Antibiotics of ESBL (-) } \\
\text { Klebsiella spp.and } \\
\text { E. coli strains (\%) }\end{array}$ & $\begin{array}{c}\text { Susceptibility } \\
\text { rates of ESBL (+) } \\
\text { Klebsiella spp. and } \\
\text { E. coli strains (\%) }\end{array}$ & p \\
\hline Ciprofloxacin & 81.4 & 48.1 & $<0.0001$ \\
Levofloxacin & 85.5 & 50.0 & $<0.0001$ \\
Ofloxacin & 81.4 & 46.2 & $<0.0001$ \\
Moxifloxacin & 81.4 & 46.2 & $<0.0001$ \\
Gentamicin & 99.0 & 37.0 & $<0.0001$ \\
Amikacin & 99.0 & 96.2 & 0.131 \\
Netilmicin & 97.9 & 57.3 & $<0.0001$ \\
\hline
\end{tabular}

\section{MIC Values of the Antibiotics}

For aminoglycosides, we determined that the MIC (inhibiting 50\% and $90 \%$ of the strains in ESBL-positive strains compared to ESBL-negative strains) increased significantly. When the increase was considered in terms of the MIC inhibiting $50 \%$ of the strains, we found out that MIC was 2 dilutions higher for amikacin, 7 dilutions higher for gentamicin, and 5 dilutions higher for netilmicin. Considering the antibiotics in the quinolone group, the MIC inhibiting $90 \%$ of the ESBL-negative and positive strains were not different for ciprofloxacin and ofloxacin and were high $(32 \mu \mathrm{g} / \mathrm{ml})$ in both groups and that this value increased 1 dilution for levofloxacin and 2 dilutions for moxifloxacin in ESBL-positive strains. When the comparison was made on the MIC inhibiting 50\% of the strains, we reached that this concentration was 6-10 dilutions higher for all quinolone group antibiotics in ESBL-positive strains than in ESBL-negative strains (Table 4). 


\begin{tabular}{|c|c|c|c|c|c|c|c|}
\hline \multicolumn{4}{|c|}{ ESBL-negative Klebsiella spp. and E. coli strains (n=97) } & \multicolumn{4}{|c|}{ ESBL-positive Klebsiella spp. and E. coli strains $(\mathrm{n}=54)$} \\
\hline Antibiotics & $\operatorname{MIC}(\mu \mathrm{g} / \mathrm{ml})$ & MIC50 & MIC90 & Antibiotics & $\operatorname{MIC}(\mu \mathrm{g} / \mathrm{ml})$ & MIC50 & MIC90 \\
\hline Ciprofloxacin & $0.06-32$ & 0.06 & 32 & Ciprofloxacin & $0.06-32$ & 32 & 32 \\
\hline Levofloxacin & $0.06-32$ & 0.06 & 8 & Levofloxacin & $0.06-32$ & 4 & 32 \\
\hline Ofloxacin & $0.06-32$ & 0.125 & 32 & Ofloxacin & $0.06-32$ & 8 & 32 \\
\hline Moxifloxacin & $0.06-32$ & 0.125 & 16 & Moxifloxacin & $0.06-32$ & 8 & 32 \\
\hline Gentamicin & $0.5-128$ & 0.5 & 1 & Gentamicin & $0.5-128$ & 64 & 128 \\
\hline Amikacin & $0.5-128$ & 2 & 4 & Amikacin & $1-64$ & 8 & 16 \\
\hline Netilmicin & $0.5-128$ & 0.5 & 2 & Netilmicin & $0.5-128$ & 16 & 32 \\
\hline
\end{tabular}

\section{DISCUSSION}

Beta-lactamase production is the most common mechanism of resistance to beta-lactam antibiotics. (7). The genes responsible for producing these enzymes may be located on chromosomes, transposons, or plasmids. More than 400 beta-lactamases have been identified today $(7,8)$. Beta-lactamase production is rare among Grampositive strains and is mostly reported in Staphylococcus aureus and Enterococus faecalis strains. It is stated that these enzymes are highly susceptible to mutation (8). These mutations lead to ESBL formation, which creates resistance to many beta-lactam antibiotics, including fourth-generation cephalosporins. The prevalence of ESBL, which was first defined in 1983, has increased dramatically since that date (9). The first species determined to produce ESBL was Klebsiella spp., followed by E. coli (10). It is reported that ESBL-producing bacteria are more frequently isolated in special departments of hospitals with intensive antibiotic use, such as intensive care units, hematology units, transplantation centers, and burn units $(11,12)$.

Previous surveillance studies identified ESBL-producing Enterobacteriaceae species all over the world (13). Their incidences may differ from country to country, as well as among hospitals. The relevant literature suggests that the ESBL positivity rate is the highest in Eastern Europe and South America (58.7-51.9\% for Klebsiella pneumoniae (K. pneumoniae); $28.9-18.1 \%$ for E. coli) and the lowest in Northern Europe and North American countries (16.7-12.3\% for K. pneumoniae; $6.2-7.5 \%$ for E. coli) $(13,14)$. In another study examining more than 4000 ESBL-producing strains in Europe, the most common ESBL-producing bacteria were K. pneumoniae, Klebsiella oxytoca, P. mirabilis, and E. coli. Among the countries included in that study, Turkey, Israel, and Greece took the first three places (14).

Two large-scale multicenter studies, including our country, investigated the susceptibilities of hospital-acquired Gramnegative strains to broad-spectrum antibiotics $(15,16)$. In these studies, ESBL positivity was determined at a rate of $25-31 \%$ for E. coli and $35-48 \%$ for Klebsiella spp. Studies conducted in Turkey report quite different rates for ESBL positivity $(16,17)$. In general, the ESBL production rate reaches $20 \%$ in E. coli strains and up to $50 \%$ in Klebsiella spp. strains (15).In our study, the ESBL positivity rates in Klebsiella spp. and E. coli strains, which are bacteremia agents, were found to be $35.5 \%$ and $48.6 \%$, respectively. These ESBL rates generally comply with the data in Turkey, but they were higher in E. coli strains (18). We think that the higher rates in this study may be since our hospital is a center with units where antibiotic use is intense, such as burn, dialysis, and transplantation units $(18,19)$. Besides, we considered studying each strain isolated from patients followed at different periods, but we could not determine the genetic origins of our ESBL-producing strains using molecular methods. Therefore, we could not suggest whether the studied E. coli strains were epidemic strains, which may be the reason for high ESBL production in $E$. coli strains (19).

While carbapenems, beta-lactam/beta-lactamase inhibitor combinations, aminoglycosides, and quinolones can be used to treat infections caused by ESBL-producing microorganisms, penicillins, cephalosporins, and aztreonam have no place in these therapies $(20,21)$. It is strongly recommended to use carbapenem group antibiotics, especially in treating severe infections with these bacteria $(22,23)$. It is well-known that carbapenems are effective not only against ESBL or non-ESBL enzymes synthesized by plasmids but also against chromosomal beta-lactamases (23). In studies evaluating the efficacy of carbapenems in ESBL-producing E. coli and Klebsiella spp. strains in Turkey and abroad, researchers determined that the carbapenem susceptibility rates of these strains were quite high $(99 \%)(14,15)$. However, intensive use of carbapenems is always shown to cause widespread production of metallo-beta-lactamase and serine protease and, consequently, leads to carbapenem-resistant Acinetobacter spp., Stenotrophomonas maltophilia, and $P$. aeruginosa infections $(24,25)$. This situation rather limits the choice of antibiotics for the treatment of severe nosocomial conditions that develop with ESBL positive bacteria (25). Therefore, scholars scrutinize the role of non-beta-lactam antibiotics, especially quinolones and aminoglycosides, in the treatment. There are few studies evaluating the in vivo and in vitro efficacies of non-beta- 
lactam antibiotics for these bacteria $(26,27)$. The relevant research showed resistance to various antibiotics, such as aminoglycosides, quinolone, tetracycline, chloramphenicol, and trimethoprim-sulfamethoxazole, can be found simultaneously in ESBL-producing bacteria, depending on the presence of multiple resistance genes $(28,29)$.

The present study provides a general approach to susceptibility rates of ESBL-producing strains to nonbeta-lactam antibiotic groups. The ability of this group of antibiotics to be used in the treatment of infections caused by ESBL-producing strains is important in terms of preserving the efficacies of high-cost and last-option antibiotics, such as carbapenems. In our hospital, until obtaining the results of antibiotic susceptibility, we prefer amikacin to carbapenem in an infection determined to produce ESBL. Fluoroquinolones have no place in alternative treatment for strains in our hospital. Since our hospital has units with a high risk of ESBL (burn, dialysis, and transplantation units), amikacin may be included in the treatment scheme considering other factors and the possibility of ESBL in cases where the infectious agent has not yet been identified and empirical treatment should be initiated.

Aminoglycosides are antibiotics known to be particularly effective against Gram-negative microorganisms, which are the agents of nosocomial infections (30). The most common mechanism of acquired aminoglycoside resistance in Gram-negative bacteria is the modification of these antibiotics by bacterial enzymes. Aminoglycoside resistance observed through enzymes was previously detected against mainly kanamycin, gentamicin, tobramycin, netilmicin, and amikacin (30). The aminoglycoside specificities of aminoglycoside modifying enzymes (AMEs) are different from each other, and many Gram-negative bacteria are able to synthesize one or more AMEs. Also, most AMEs can inactivate multiple aminoglycosides. As a result, the specific resistance to an aminoglycoside group antibiotic does not provide information about resistance to others $(30,31)$. It is also stated that regional enzyme differences are observed for AMEs. For example, enzyme types inactivating gentamycin are detected more frequently in the United States of America, whereas those inactivating amikacin are observed in Japan (31). In a study conducted in our country, one or more AMEs were found in gramnegative isolates resistant to aminoglycoside, and these enzymes were found to be frequently responsible for tobramycin, amikacin, netilmicin, and kanamicin resistance $(31,32)$. Studies on ESBL-positive isolates yielded different results regarding aminoglycoside susceptibility. Studies showed that aminoglycoside resistance was significantly higher in ESBL-producing E. coli and Klebsiella spp. strains compared to non- producing ones, and the resistance reached $70 \%$ to amikacin and gentamicin (32). In multicenter studies conducted in our country, resistance rates to amikacin varied between $41-46 \%$ in ESBL-positive strains $(33,34)$. However, there was also a study in which the rate of amikacin resistance in these strains was found to be very low $(1 \%)(34,35)$. Another study in our country revealed that $94.5 \%$ of ESBL-positive E. coli strains and $83.3 \%$ of $K$. pneumoniae strains were susceptible to amikacin and that amikacin was the antibiotic least affected by ESBL production $(34,35)$. In studies conducted in our country, the researchers reported that amikacin susceptibility was high regardless of ESBL production (35). Surveillance studies showed that the in vitro efficacy of gentamicin was poor, although the susceptibility to aminoglycoside antibiotics did differ significantly in ESBL-producing microorganisms (35). Nevertheless, we could not reach data on susceptibility rates of ESBL-producing strains to netilmicin.

In our study, the aminoglycoside group antibiotic with the highest susceptibility rate with ESBL-producing and non-producing isolates was amikacin, and this result was similar to that in the literature. Susceptibility rates of ESBL-producing strains both to gentamicin and netilmicin decreased significantly $(\mathrm{p}<0.05)$, whereas MIC inhibiting $50 \%$ and $90 \%$ of the strains increased significantly. On the other hand, although the MIC values of amikacin, inhibiting $50 \%$ and $90 \%$ of ESBLpositive strains, were found to be high, we discovered that there was no significant difference in susceptibility rates in these two groups. We think that this difference observed in the resistance pattern may be due to AME types carried by the same plasmid.

Quinolone group antibiotics are among the widely used antibiotics. In recent years, increasing resistance has been observed against this group of antibiotics, especially in Gram-negative bacteria (36). ESBL production and quinolone resistance can coexist in these bacteria. In the literature, ESBL production was detected in $60 \%$ of ciprofloxacin-resistant K. pneumoniae strains $(36,37)$. Similarly, many studies on the subject observed that ciprofloxacin resistance increased in ESBL-producing strains (37). The mechanism of this association has not been fully elucidated; however, there are studies indicating that this resistance can be explained by the coexistence of different mechanisms, such as plasmid-mediated quinolone resistance genes in ESBL production, outer membrane protein changes, or active efflux pump $(38,39)$. Studies in the national literature reported that ESBLproducing Klebsiella spp. and E. coli strains bear resistance to quinolones at a rate of $30-48 \%$ (40). In our study, nonESBL producing strains showed a susceptibility rate of $81.4 \%-85.5 \%$ to quinolones (ciprofloxacin, levofloxacin, 
ofloxacin, and moxifloxacin). In contrast, we observed susceptibility significantly decreased in ESBL-producing strains. In addition, we determined that the values of MIC inhibiting $90 \%$ of all strains included in the study, independent of ESBL production, for quinolones were at the resistance limits. We think that it stems from the high quinolone resistance that develops because of improper use of quinolone group antibiotics in many infectious diseases, especially urinary system infections.

Kinıklı et al. (41) and Savc1 et al. (42) also addressed antibiotic resistance in their studies, and these studies generally concludes that antibiotic resistance is an increasingly important problem.

Since most studies with ESBL-producing bacteria focus on the epidemiology, detection methods, and molecular characteristics of ESBL in daily laboratory practices, there are rather limited in vitro and in vivo data on antibiotics to be preferred in the treatment of infections with these bacteria. Although these data are very limited and include local data (e.g., a single hospital), it is essential to carry out similar studies to determine the antibiotic susceptibility profiles of ESBL strains in cities and countries. It should be noted that the results of a small number of centers are presented as the data of our country in the international studies, which hinders accessing accurate and useful data.

\section{CONCLUSION}

In our study, we determined that resistance to all studied quinolone and aminoglycoside antibiotics, except for amikacin, significantly increased in ESBL-producing Klebsiella spp. and E. coli strains. This situation will further limit our treatment options in the future if relevant precautions are not taken. We think that the outbreaks caused by these ESBL-producing strains will decrease thanks to the rational use of antibiotics and the implementation of barrier measures.

\section{ETHICAL DECLARATIONS}

Ethics Committee Approval: We obtained the relevant approval for our study from Başkent University, NonInvasive Health Research Ethics Committee (Date: 11.05.2005, Decision No: 2004/AP-577).

Informed Consent: Any written consent was not required, as laboratory data without biological materials were used in this study.

\section{Referee Evaluation Process: External double-blind review.}

Conflict of Interest Statement: The authors declare that there is no interest-based relationship in this study.

Financial Disclosure: The authors declare that this study did not receive any financial support.
Author Contributions: All the authors declare that they participated in the design, execution, and analysis of the study and approved the final version of the manuscript.

\section{REFERENCES}

1. Bush K, Bradford PA. Epidemiology of $\beta$-lactamase-producing pathogens. Clin Microbiol Rev 2020; 33: e00047-19

2. Bonomo RA. $\beta$-Lactamases: A focus on current challenges. Cold Spring Harb Perspect Med 2017; 7: a025239.

3. Bush K. Past and present perspectives on $\beta$-lactamases. Antimicrob Agents Chemother 2018; 62: e01076-18.

4. Tooke CL, Hinchliffe P, Bragginton EC, et al. $\beta$-lactamases and $\beta$-lactamase inhibitors in the $21^{\text {st }}$ century. J Mol Biol 2019; 431: 3472-500.

5. Bauvois $C$, Wouters J. Crystal structures of class $C \beta$-lactamases: Mechanistic implications and perspectives in drug design. In enzyme-mediated resistance to antibiotics: Mechanisms, dissemination, and prospects for inhibition (ed. Bonomo RA, Tolmasky ME), ASM, Washington DC, 2007, pp:145-161.

6. Institute/NCCLS CaLS. Performance standarts for antimicrobial susceptibility testing; Fifteenth Informational Supplement. CLSI/ NCCLS document. Clinical and Laboratory Standarts Institute, Wayne, Pennsylvania, 2005, pp:19087-1898.

7. Bush K. Bench-to-bedside review: The role of $\beta$-lactamases in antibiotic-resistant Gram negative infections. Crit Care 2010; 14: 224.

8. Bush K, Jacoby GA. Updated functional classification of $\beta$-lactamases. Antimicrob Agents Chemother 2010; 54: 969-76.

9. Sturenburg E, Mack D. Extended-spectrum beta-lactamases: implications for the clinical microbiology laboratory, therapy, and infection control. J Infect 2003; 47: 273-95.

10.Paterson DL, Bonomo RA. Extended-spectrum $\beta$-lactamases: A clinical update. Clin Microbiol Rev 2005; 18: 657-86.

11.Abdelaziz MO, Bonura C, Aleo A, et al. OXA-163-producing Klebsiella pneumoniae in Cairo, Egypt, in 2009 and 2010. J Clin Microbiol 2012; 50: 2489-91.

12.Lu S, Soeung V, Nguyen HAT, et al. Development and evaluation of a novel protein-based assay for specific detection of KPC $\beta$-lactamases from Klebsiella pneumoniae. mSphere 2020; 5: e00918-19.

13. Juan C, Torrens G, Barceló IM, et al. Interplay between peptidoglycan biology and virulence in gram-negative pathogens. Microbiol Mol Biol Rev 2018; 82: e00033-18.

14. Nijssen S, Florijn A, Bonten MJ, et al. Beta-lactam susceptibilities and prevalence of ESBL-producing isolates among more than 5000 European Enterobacteria ceae isolates. Int J Antimicrob Agents 2004; 24: 585-91.

15. Gülay Z. Gram-negatif çomaklarda antibiyotik direnci. Ankem Derg 2005; 19: 66-77.

16. Jones RN, Pfaller MA; MYSTIC Study Group (Europe). Antimicrobial activity against strains of Escherichia coli and Klebsiella spp. with resistance phenotypes consistent with an extended-spectrum beta-lactamase in Europe. Clin Microbiol Infect 2003; 9: 708-12.

17.Jiang W, Yang W, Zhao X, et al. Klebsiella pneumoniae presents antimicrobial drug resistance for $\beta$-lactam through the ESBL/PBP signaling pathway. Exp Ther Med 2020; 19: 2449-56.

18. Fouhy F, Motherway MO, Fitzgerald GF, et al. In silico assigned resistance genes confer bifidobacterium with partial resistance to aminoglycosides but Not to B-Lactams. PLoS One 2013; 8: e82653.

19. Mumcuoğlu İG, Baydur T. Escherichiae, Klebsiella ve Proteus suşlarında genişlemiş spektrumlu beta-laktamaz varlığ ve çeşitli antibiyotiklere direnç durumu. Ankem Derg 2004; 18: 9. 
20. Paterson DL, Ko WC, Von Gottberg A, et al. Outcome of cephalosporin treatment for serious infections due to apparently susceptible organisms producing extended-spectrum betalactamases: implications for the clinical microbiology laboratory. J Clin Microbiol 2001; 39: 2206-12.

21. Wong-Beringer A. Therapeutic challenges associated with extended-spectrum, beta-lactamase-producing Escherichia coli and Klebsiella pneumoniae. Pharmacotherapy 2001; 21: 583-92.

22.Heng ST, Chen SL, Wong JGX, et al. No association between resistance mutations, empiric antibiotic, and mortality in ceftriaxone-resistant Escherichia coli and Klebsiella pneumoniae bacteremia. Sci Rep 2018; 8: 12785.

23. RamphalR, Amnbrose PG. Extended-spectrum beta-lactamases and clinical outcomes: current data. Clin Infect Dis 2006; 42: 164-72.

24. Lautenbach E, Strom BL, Bilker WB, et al. Epidemiological investigation of fluoroquinolone resistance in infections due to extended-spectrum beta-lactamase-producing Escherichia coli and Klebsiella pneumoniae. Clin Infect Dis 2001; 33: 1288-94.

25. Patterson JE. Antibiotic utilization: is there an effect on antimicrobial resistance? Chest 2001; 119: 426-30.

26. Paterson DL. Recommendation for treatment of severe infections caused by Enterobacteriaceae producing extended-spectrum betalactamases (ESBLs). Clin Microbiol Infect 2000; 6: 460-3.

27. Essack SY. Treatment options for extended-spectrum betalactamase-producers. FEMS Microbiol Lett 2000; 190: 181-4.

28. Winokur RC, Caselles JM, and Legakis N. Variations in the prevalence of strains expressing an extended-spectrum betalactamase phenotype and characterization of isolates from Europe, the Americas, and the Western Pacific region. Clin Infect Dis 2001; 32: 94-103.

29. Ambrose RR. Extended-spectrum beta-lactamases and clinical outcomes: current data. Clin Infect Dis 2006; 42.

30. Leblebicioglu H, Gunaydin M, Esen S, et al. Surveillance of antimicrobial resistance in Gram-negative isolates from intensive care units in Turkey: analysis of data from the last 5 years. J Chemother 2002; 14: 140-6.

31. Yu Y, Zhou W, Chen Y, et al. Epidemiological and antibiotic resistant study on extended-spectrum beta-lactamase-producing Escherichia coli and Klebsiella pneumoniae in Zhejiang Province. Chin Med J (Engl) 2002; 115: 1479-82.

32. Sahin İK, Öksüz D, Okay S, et al. Klinik örneklerden izole edilen Gram-negatif çomaklarda genişlemiş spektrumlu beta-laktamaz sıklı̆̆ı ve antibiyotik duyarlılığı. İnffeksiyon Derg 2003; 17: 45-8.

33. Özbilge HY, İnanç F. Gram-negatif çomaklarda genișlemiș spektrumlu beta-laktamaz varlığı ve çeşitli antibiyotiklere direnç durumu. Ankem Derg 2003; 17: 13-5.

34.Zer YB, Orhan A, Celiksöz G, Korkmaz C, et al. Hastanede yatan hastalarda izole edilen gram negative çomaklarda genişlemiş spektrumlu beta-laktamazların ve çeșitli antibiyotiklere duyarlılığın araştırılması. Anadolu Tip Derg 2002; 4: 71-5.

35. Jones RN, Pfaller MA. Antimicrobial activity against strains of Escherichia coli and Klebsiella spp. with resistance phenotypes consistent with an extended-spectrum beta-lactamase in Europe. Clin Microbiol Infect 2003; 9: 708-12.

36. Domenech-Sanchez A, Pascual A, Suarez AI, et al. Activity of nine antimicrobial agents against clinical isolates of Klebsiella pneumoniae producing extended-spectrum beta-lactamases and deficient or not in porins. J Antimicrob Chemother 2000; 46: 858-9.

37. Sekowska A JG, Keyszejko C, Wojda M, et al. Resistance of Klebsiella pneumoniae strains producing and not producing ESBL (extendedspectrum beta-lactamase) type enzymes to selected non-betalactam antibiotics. Med Sci Monit 2002; 8: 100-4.

38. Babini GS, Livermore DM. Antimicrobial resistance amongst Klebsiella spp. collected from intensive care units in Southern and Western Europe in 1997-1998. J Antimicrob Chemother 2000; 45 183-9.
39. Kizirgil A, Demirdag K, Ozden M, et al. In vitro activity of three different antimicrobial agents against ESBL producing Escherichia coli and Klebsiella pneumoniae blood isolates. Microbiol Res 2005; 160: $135-40$.

40. Rice LB. Evolution and clinical importance of extented spectrum beta lactamases. Chest 2001; 119: 391-6.

41.Kınıklı S, Cesur S, Yücel M, Ataman Hatipoğlu Ç, Dinç B. Determination of polymyxin B, minocycline, colistin and phosphomycin susceptibilities in Acinetobacter baumannii strains showing carbapenem resistant multidrug resistance phenotype. J Health Sci Med 2019; 2: 49-53.

42. Savcı Ü, Şahin M, Toprak S, Sungur M. Antimicrobial resistance pattern of Streptococcus agalactiae strains: five years evaluation of single center. J Health Sci Med 2018; 1: 25-8. 